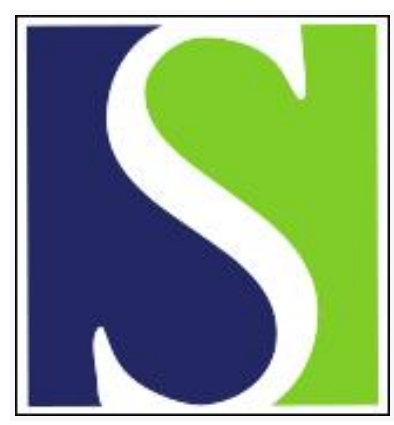

Scand J Work Environ Health 1991;17(2):117-122

https://doi.org/10.5271/sjweh.1726

Issue date: Apr 1991

Feeding and bedding materials as sources of microbial exposure on dairy farms.

by Kotimaa MH, Oksanen L, Koskela P

Affiliation: Kuopio Regional Institute of Occupational Health, Finland.

This article in PubMed: www.ncbi.nlm.nih.gov/pubmed/2047813

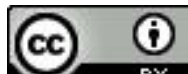




\title{
Feeding and bedding materials as sources of microbial exposure on dairy farms
}

\author{
Marjut H Kotimaa, LSc ${ }^{1}$, Leena Oksanen, LVM², Pentti Koskela, PhD ${ }^{3}$
}

\begin{abstract}
KOTIMAA MH, OKSANEN L, KOSKELA P. Feeding and bedding materials as sources of microbial exposure on dairy farms. Scand J Work Environ Health 1991:17:117-22. Hay, grain, silage, and bedding are the sources of mold dust in agriculture. The aim of the present study was to evaluate the effect of different farming methods on exposure to airborne microbes. The study material comprised 50 silage, 54 hay, 47 grain, and 70 bedding samples taken on 18 farms in the beginning, middle, and end of the indoor feeding season. The modified wind-tunnel technique and six-stage impactors were used to determine the number of mesophilic bacteria, xerophilic fungi, mesophilic fungi, thermotolerant fungi, and thermophilic actinomycetes liberated from each material. Baled hay and straw liberated the largest amounts of microbes. Hay, except when dried in storage, liberated great numbers of fungal spores. The proportion of respirable airborne microbe-bearing particles was greatest in the highest concentrations. Theoretically, choosing the best possible alternative work methods could diminish exposure to microbes to onetenth of the present level.
\end{abstract}

Key terms: bacteria, fungal spores, thermophilic actinomycetes, work methods.

The yearly incidence of allergic alveolitis or hypersensitivity pneumonitis has increased in Finland from 101 cases in 1984 (1) to 340 cases in $1988(2-5)$. Most of the cases involving people on farms where high concentrations of airborne microbes are present in the work environment, for example, animal confinement buildings and storage areas for feed. High microbial concentrations are due to the handling of a variety of microbe-containing materials and the presence of animals and their excrement. The causative agents of farmer's lung or the exposing agents of farmer's lung patients include the thermophilic actinomycetes Thermoactinomyces candidus, Thermoactinomyces vulgaris, and Faenia rectivirgula (according to the former taxonomy, Thermoactinomyces vulgaris, Thermoactinomyces thalpophilus, and Micropolyspora faeni, respectively), the thermotolerant fungus Aspergillus fumigatus and the xerophilic fungus Aspergillus umbrosus, which are abundant in moldy hay (6), but not necessarily in other moldy materials (7). The mechanism of molding has been primarily investigated for hay $(8,9)$ and grain $(10,11)$. The most important factor affecting molding is the water activity and not the water content of the material (12).

The methods of making and collecting hay and the methods of storing grain also affect the nutritional and microbiological quality of the material. In general, we

${ }^{1}$ Kuopio Regional Institute of Occupational Health, Kuopio, Finland.

2 Department of Animal Husbandry, University of Helsinki, Helsinki, Finland.

${ }^{3}$ National Public Health Institute, Kuopio, Finland.

Reprint requests to: Ms MH Kotimaa, Kuopio Regional Institute of Occupational Health, POB 93, SF-70701 Kuopio, Finland. know the possible sources of mold dust in agriculture, but there are no reports of the mutual importance of different sources in practice. The aim of the present study was to evaluate the effect of different work methods on the exposure to airborne microbes during one indoor feeding season through measurement of the amounts of microbes liberated from different feeding and bedding materials used on farms and the investigation of the species and the fraction of microbial dust with an aerodynamic diameter of $<5 \mu \mathrm{m}$. In addition the seasonal variation in the amount and species of liberated microbes was studied.

\section{Materials and methods}

The study material consisted of 221 samples, of which 50 were silage, 54 hay, 47 grain, and 70 bedding materials. The samples were collected from 18 Finnish farms in northern Savo three times during the indoor feeding season of 1985-1986 (in October, January, and May). The farms used different methods of making hay or storing grain and also different kinds of bedding material. On eight farms hay was baled but not dried in storage, on seven farms hay was dried on poles and collected loosely. Two farms had storage driers for baled hay, and on one farm hay was dried on the ground and collected loosely into storage. Grain was dried by forced unheated air on eight farms, on five farms it was dried by heated forced air, and on six farms it was preserved by acid treatment. One of the aforementioned farms used both drying with unheated air and acid treatment for grain. Eleven farms used straw, eleven used wood shavings, and one used saw dust for bedding. Five of these farms used both straw and wood shavings as bedding material. The work 

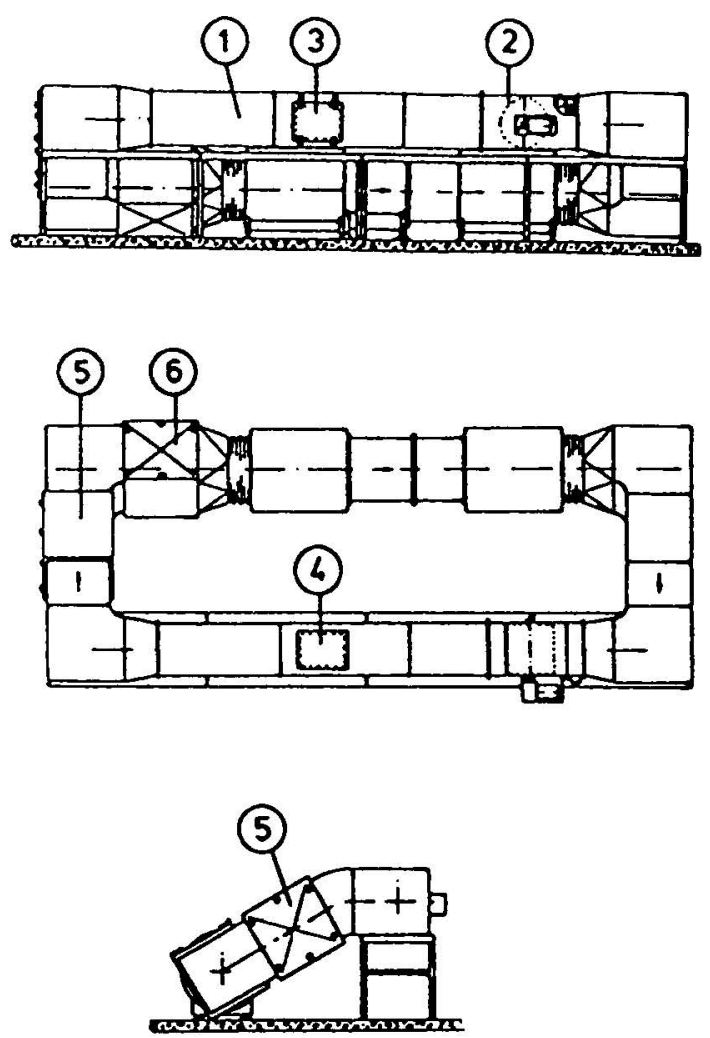

Figure 1. Scheme of the wind-tunnel used to investigate the liberation of microbes from feed and bedding. ( $1=$ rectangular duct, $50 \mathrm{~cm} \times 50 \mathrm{~cm} ; 2$ = perforated drum for material sample; $3=$ hatch for placing the impactors into the duct; $4=$ window $5=$ filter, HI-FLO super $3-M ; 6=$ filter, MICRETAIN 7-D-100) methods used on these farms represented the most widely used methods in Finnish agriculture.

The modified wind-tunnel technique was used in the microbiological investigations (figure 1). Originally the method was described by Gregory \& Lacey (13), who used through air flow instead of circulating air. In turn $20 \mathrm{~g}$ of silage, $50 \mathrm{~g}$ of grain, $10 \mathrm{~g}$ of hay, and $20 \mathrm{~g}$ of bedding material were put into the perforated drum of the wind tunnel. The drum was rotated $1 \mathrm{round} / \mathrm{s}$ and the wind speed was about $4 \mathrm{~m} / \mathrm{s}$ during the sampling. The drum was cleaned with a vacuum cleaner and wiped with $70 \%$ ethanol between each sampling.

Six-stage Andersen impactors (model 10-800, Andersen Inc, Georgia, United States) were placed two or three at a time downwind $2 \mathrm{~m}$ from the drum and facing the wind to collect the microbes liberated from each sample (14). The total numbers of mesophilic bacteria were counted from tryptone-glucose-yeast-extract agar after $5 \mathrm{~d}$ of incubation at $20^{\circ} \mathrm{C}$. The medium and incubation temperature for the other microbe groups (ie, xerophilic fungi, mesophilic fungi, thermotolerant fungi, and thermophilic actinomycetes) have been given in another report (15). A total of 1105 air samples was collected for the microbiological analysis.

After incubation, the number of colonies was counted, and positive hole correction was done according to Andersen (14). The colonies of fungi and thermophilic actinomycetes were identified with light microscopy for the determination of the morphological details and the comparison of the structures with those in the literature. Standard texts and keys were used. The results have been expressed as colonyforming units per gram of material $(\mathrm{cfu} / \mathrm{g})$.

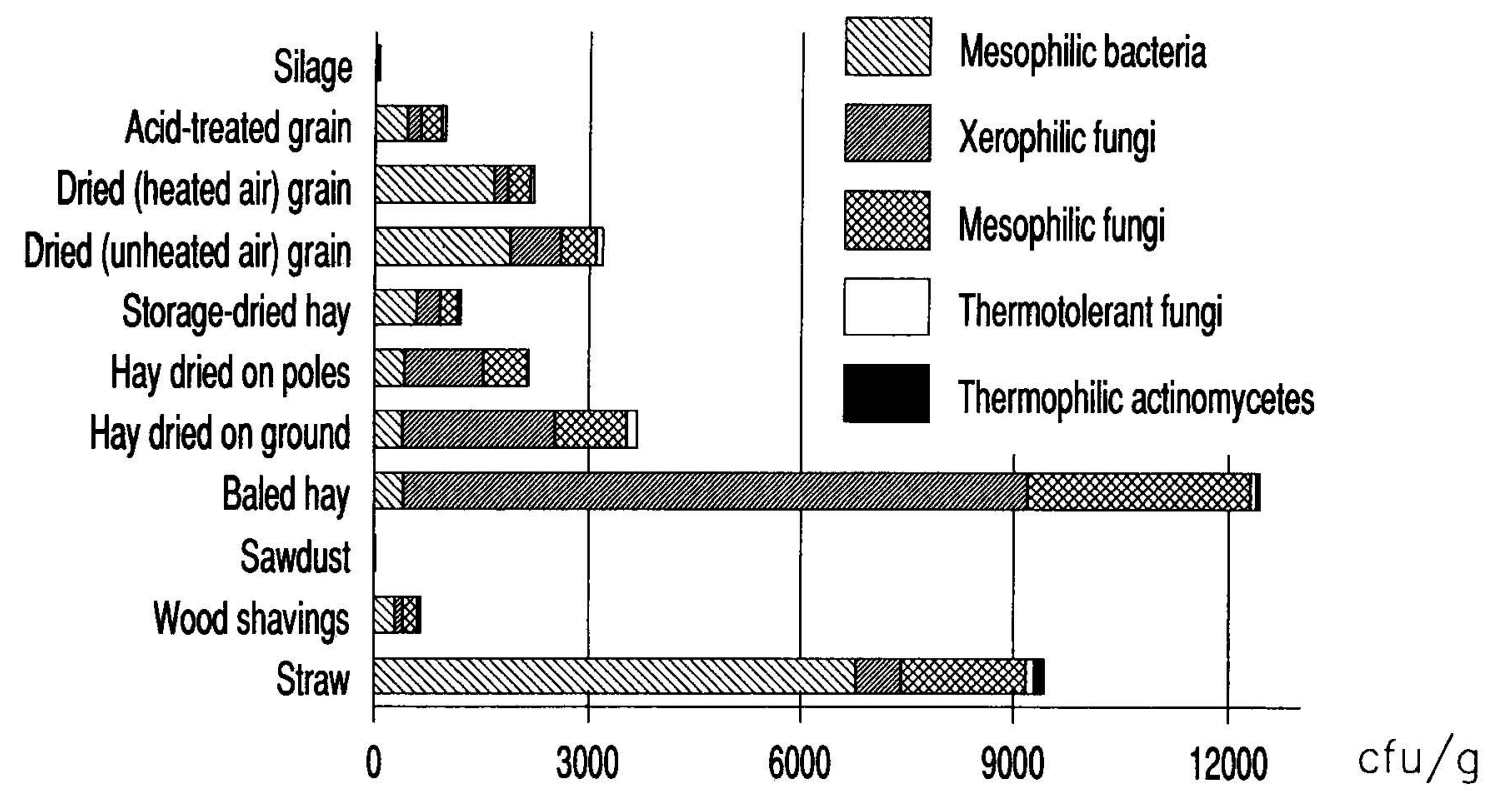

Figure 2. Average amounts of various microbes (colony-forming units/gram), liberated from different types of dairy cattle feed and bedding. 
The proportion of the fraction of microbial dust with an aerodynamic diameter of $<5 \mu \mathrm{m}$ was calculated from the particle size distribution stated for the impactor (14).

The evaluation of the effect of different work methods on the exposure to microbes was based on the average amounts of feeding and bedding material used daily for dairy cows in Finland. When cows are fed mainly dried hay, the daily amount of silage is about $10 \mathrm{~kg} / \mathrm{cow}$, that of hay $10 \mathrm{~kg} / \mathrm{cow}$, and that of grain $7 \mathrm{~kg} / \mathrm{cow}$. When the main feed is silage, the corresponding amounts are $20 \mathrm{~kg} / \mathrm{cow}, 2 \mathrm{~kg} / \mathrm{cow}$, and $9 \mathrm{~kg} / \mathrm{cow}$, respectively. The solid manure system requires daily kilograms of bedding material for one cow in contrast to hundreds of grams for the liquid manure system.

In the evaluation of the differences in the materials as sources of exposure to microbes, the one-way analysis of variance was used after the logarithmic transformation of the calculated values.

\section{Results}

Baled hay and straw liberated the greatest amounts of microbes (figure 2). Mesophilic bacteria were abundant in the airborne microflora originating from grain and straw during the whole indoor feeding season. Hay, except when dried in storage, liberated great num- bers of fungal spores, mainly those of mesophilic fungi (eg, Penicillium and Aspergillus species (table 1). Moist materials such as silage and saw dust (used as bedding material) caused significantly $(\mathrm{P}<0.001)$ minor exposure to microbes in comparison with the other materials. Xerophilic fungi (Aspergillus umbrosus and Aspergillus repens) were abundant in baled hay and hay dried on poles. High concentrations of the spores of thermotolerant fungi (Aspergillus fumigatus, $A b$ sidia $s p$, Humicola $s p$, Paecilomyces variotil) were liberated from baled hay in the autumn and from straw in spring at the end of the indoor feeding season. The spores of thermophilic actinomycetes, mostly those of Thermoactinomyces candidus, were generated in great numbers (more than $10^{4} \mathrm{cfu} / \mathrm{g}$ ) only by straw in the autumn and spring, but not in midwinter. The prevalences of different fungal and actinomycetal species or genera found in feeding and bedding material are presented in table 1 .

All the materials showed a fluctuation in the microbe concentration with time (table 2), although the changes in the amounts of liberated microbes were statistically significant only for silage ( $\mathrm{P}<0.001)$ and for wood shavings $(\mathrm{P}<0.05)$. Silage, straw, and all types of hay liberated the smallest amounts of microbes in midwinter in contrast to grain and wood shavings.

The proportion of airborne, microbe-bearing particles smaller than $5 \mu \mathrm{m}$ was greatest in the highest

Table 1. Prevalence (\%) of different fungal and actinomycetal species found in grain, silage, hay, and bedding materials.

\begin{tabular}{|c|c|c|c|c|c|}
\hline Genus or species & Grain & Silage & Hay & Bedding & Total \\
\hline Absidia species & 60 & 26 & 65 & 58 & 52 \\
\hline Alternaria species & 11 & 0 & 4 & 4 & 4 \\
\hline Aspergillus species & 32 & 50 & 87 & 56 & 60 \\
\hline Aspergillus candidus & 4 & 0 & 2 & 0 & 1 \\
\hline Aspergillus conicus & 0 & 0 & 0 & 2 & $<1$ \\
\hline Aspergillus flavus & 2 & 0 & 0 & 0 & $<1$ \\
\hline Aspergillus fumigatus & 57 & 10 & 54 & 56 & 44 \\
\hline Aspergillus niger & 6 & 0 & 15 & 8 & 7 \\
\hline Aspergillus nivale & 4 & 0 & 0 & 0 & 1 \\
\hline Aspergillus ochraceus & 2 & 0 & 0 & 0 & $<1$ \\
\hline Aspergillus repens & 30 & 48 & 57 & 28 & 41 \\
\hline Aspergillus umbrosus & 74 & 56 & 100 & 64 & 74 \\
\hline Aureobasidium pullulans & 21 & 0 & 2 & 16 & 9 \\
\hline Botrytis cinerea & 2 & 0 & 2 & 8 & 3 \\
\hline Cephalosporium species & 0 & 4 & $\overline{0}$ & 2 & 1 \\
\hline Cladosporium species & 91 & 22 & 78 & $8 \overline{8}$ & 70 \\
\hline Gilmaniella humicola & 0 & 2 & 0 & 0 & $<1$ \\
\hline Gonatobotrys simplex & 0 & 0 & 0 & 2 & $<1$ \\
\hline Humicola species & 0 & 0 & 7 & 2 & 2 \\
\hline Hyalodendron species & 0 & 0 & 0 & 4 & 1 \\
\hline Mucor species & 51 & 30 & 30 & 26 & 34 \\
\hline Oidiodendron species & 2 & 0 & 0 & 2 & 1 \\
\hline Paecilomyces variotii & 4 & 0 & 43 & 22 & 18 \\
\hline Penicillium species & 100 & 68 & 100 & 98 & 92 \\
\hline Rhizopus species & 23 & 0 & 6 & 4 & 8 \\
\hline Scopulariopsis brevicaulis & 0 & 0 & 7 & 0 & 2 \\
\hline Sporotrichum species & 0 & 0 & 6 & 0 & 1 \\
\hline Streptomyces species & 74 & 44 & 83 & 42 & 71 \\
\hline Thermoactinomyces candidus & 91 & 48 & 54 & $4 \overline{8}$ & 60 \\
\hline Thermoactinomyces vulgaris & 62 & 12 & 31 & 36 & 35 \\
\hline Thysanophora canadensis & 0 & 0 & 0 & 2 & $<1$ \\
\hline Trichoderma viride & 2 & 0 & 22 & 22 & 12 \\
\hline Trichothecium roseum & 23 & 0 & 0 & 18 & 10 \\
\hline Sterile mycelium & 47 & 18 & 61 & 58 & 46 \\
\hline Yeasts & 51 & 34 & 52 & 80 & 54 \\
\hline
\end{tabular}


Table 2. Amount of microbes (cfu/g) liberated from different materials in different seasons. (G $=$ geometric, NS $=$ not significant, cfu $=$ colony-forming units)

\begin{tabular}{|c|c|c|c|c|c|c|c|}
\hline \multirow{3}{*}{ Material } & \multicolumn{7}{|c|}{ Season } \\
\hline & \multicolumn{2}{|c|}{ Autumn } & \multicolumn{2}{|r|}{ Winter } & \multicolumn{2}{|r|}{ Spring } & \multirow[t]{2}{*}{ P-value } \\
\hline & $\mathrm{G}$ mean & Range & G mean & Range & $\mathrm{G}$ mean & Range & \\
\hline $\begin{array}{l}\text { Silage } \\
\text { Grain treated with acid } \\
\text { Grain dried with warm air } \\
\text { Grain dried with cool air } \\
\text { Hay dried in storage } \\
\text { Hay dried on poles } \\
\text { Baled hay } \\
\text { Wood shavings } \\
\text { Straw }\end{array}$ & $\begin{array}{r}89 \\
980 \\
1600 \\
3100 \\
2400 \\
1500 \\
18000 \\
69 \\
8700\end{array}$ & $\begin{array}{c}48-210 \\
270-12000 \\
650-7700 \\
270-9100 \\
1500-3200 \\
280-38000 \\
1400-47000 \\
35-390 \\
2400-34000\end{array}$ & $\begin{array}{r}25 \\
1000 \\
3200 \\
3400 \\
1200 \\
1100 \\
6300 \\
480 \\
2800\end{array}$ & $\begin{array}{c}8-63 \\
180-8200 \\
920-29000 \\
1500-15000 \\
1100-1500 \\
580-17000 \\
480-52000 \\
160-30000 \\
790-39000\end{array}$ & $\begin{array}{r}97 \\
990 \\
2000 \\
3100 \\
700 \\
3900 \\
13000 \\
1500 \\
17000\end{array}$ & $\begin{array}{c}65-560 \\
160-8800 \\
1400-2900 \\
1200-15000 \\
670-750 \\
1700-15000 \\
1500-77000 \\
380-21000 \\
6600-100000\end{array}$ & $\begin{array}{l}* * * \\
\text { NS } \\
\text { NS } \\
\text { NS } \\
\text { NS } \\
\text { NS } \\
\text { NS } \\
\text { NS }\end{array}$ \\
\hline
\end{tabular}

* $P<0.05,{ }^{* * \star} P<0.001$ (statistical significance of the differences of the amount of microbes in autumn, winter, and spring)

Table 3. Percentage of microbe-bearing particles with an aerodynamic diameter of $<5 \mu \mathrm{m}$ according to the group of microbes and the concentration. The percentages have been calculated only for the concentrations $\geq 500 \mathrm{cfu} / \mathrm{m}^{3}$. (cfu $=$ colony-forming units)

\begin{tabular}{|c|c|c|c|c|c|c|c|c|c|}
\hline \multirow{3}{*}{$\begin{array}{l}\text { Group of } \\
\text { microbes }\end{array}$} & \multicolumn{9}{|c|}{ Percentage of particles $<5 \mu \mathrm{m}$} \\
\hline & \multicolumn{3}{|c|}{$500-9999 \mathrm{cfu} / \mathrm{m}^{3}$} & \multicolumn{3}{|c|}{$10000-99999 \mathrm{cfu} / \mathrm{m}^{3}$} & \multicolumn{3}{|c|}{$\geq 100000 \mathrm{cfu} / \mathrm{m}^{3}$} \\
\hline & $\begin{array}{c}\text { Number } \\
\text { of } \\
\text { samples }\end{array}$ & $\begin{array}{c}\text { Arithmetic } \\
\text { mean }\end{array}$ & SD & $\begin{array}{c}\text { Number } \\
\text { of } \\
\text { samples }\end{array}$ & $\begin{array}{l}\text { Arithmetic } \\
\text { mean }\end{array}$ & SD & $\begin{array}{c}\text { Number } \\
\text { of } \\
\text { samples }\end{array}$ & $\begin{array}{c}\text { Arithmetic } \\
\text { mean }\end{array}$ & SD \\
\hline $\begin{array}{l}\text { Mesophilic bacteria } \\
\text { Xerophilic fungi } \\
\text { Mesophilic fungi } \\
\text { Thermotolerant fungi } \\
\text { Thermophilic actinomycetes }\end{array}$ & $\begin{array}{l}93 \\
58 \\
73 \\
64 \\
38\end{array}$ & $\begin{array}{l}42.9 \\
63.7 \\
63.7 \\
58.6 \\
43.5\end{array}$ & $\begin{array}{l}16.4 \\
17.9 \\
18.3 \\
22.0 \\
17.2\end{array}$ & $\begin{array}{r}48 \\
41 \\
40 \\
15 \\
2\end{array}$ & $\begin{array}{l}64.2 \\
77.0 \\
67.7 \\
81.2 \\
66.9\end{array}$ & $\begin{array}{r}7.8 \\
12.8 \\
14.1 \\
8.7\end{array}$ & $\begin{array}{r}38 \\
28 \\
30 \\
4 \\
2\end{array}$ & $\begin{array}{l}82.9 \\
90.1 \\
85.5 \\
89.4 \\
91.4\end{array}$ & $\begin{array}{l}8.0 \\
4.1 \\
8.9 \\
4.2 \\
.\end{array}$ \\
\hline
\end{tabular}

concentrations, irrespective of the microbe group (table 3). In concentrations under $100000 \mathrm{cfu} / \mathrm{m}^{3}$, the fungi occurred as smaller particles than did the bacteria.

When the quantities of different materials used daily on dairy farms with different work methods were calculated, the role of different feeding and bedding materials in creating the exposure to microbes became evident (table 4). The worst sources of mold dust in practice proved to be baled hay, straw, hay dried on the ground and collected loosely, and grain dried with unheated forced air.

\section{Discussion}

The exact dose-response relationship between the exposure to spores and health effects is not known. Environmental and clinical studies carried out on Swedish farms have shown that nonsymptomatic farmers have very low exposure to spores and farmers with symptoms are exposed to $10^{9}$ spores $/ \mathrm{m}^{3}$ air, including both viable and nonviable microbes in the air (16). Finnish studies have given parallel results. Farmers with allergic alveolitis are exposed to about $2.7 \times 10^{6}$ $\mathrm{cfu} / \mathrm{m}^{3}$, and their healthy siblings to about $0.75 \times 10^{6}$ $\mathrm{cfu} / \mathrm{m}^{3}(17)$. These results suggest that a high exposure to microbes is necessary before respiratory symptoms, especially allergic alveolitis, develop.

The concentration of airborne microbes in the work environment of farms is principally affected by the moldiness of the materials, the physical character of the fungi (spore size, moisture content of spores), and the degree of mechanical handling of the materials. The wind-tunnel method used in the present study gives a good idea of the microbial exposure caused by each material, as reported also by Lacey \& Dutkiewicz (18).

To prevent molding, all the materials used as bedding or feed should be dried sufficiently before storage. The water content of the grain should be less than $15 \%(19)$ and that of hay less than $20 \%(20)$ or less than $16 \%$ according to Gregory \& Lacey (13). Our results showed that grain dried with heated forced air liberated microbes less than grain dried with unheated forced air. Microbiologically the safest result was achieved by flattening the grain and by treating it with a mixture of formic acid and acetic acid. In other studies good results have been obtained when grain has been treated with propionic acid (21). Appropriate work methods and protection have to be used during the handling of chemical additives to avoid health hazards from exposure to these chemicals.

The best treatment for hay was achieved with storage dryers, as reported also by Mustonen et al (22). The traditional Finnish way of making hay, drying on poles, gave satisfactory results in comparison with baled hay or hay dried on the ground and collected loosely. The chemical treatment of hay has not given good results under field conditions (9), probably due to the uneven distribution of the chemical used (23). 
Straw is the most commonly used bedding material. Other materials, such as wood shavings, sawdust or peat, are used with the dry manure system only if they are cheap and easily available from carpenters or saw mills. On the farms of this study, wood shavings were used in addition to straw. The wood shavings were usually stored in the corner of the barn, and this procedure caused a steady increase in the concentration of microbes during the indoor feeding season.

It was found that seemingly dry batches of materials were dustier and liberated more microbes than wet materials like sawdust or silage. The proportion of respirable microbe-bearing particles was greatest when the total concentration of microbes was high. This finding may have been due to the fact that most socalled storage fungi characteristically have spores which are small and dry and are thus easily detached from spore-forming organs. Although bacteria are small in size, they often occur as aggregates and were therefore seen in our study material in the fraction of greater particles than were fungal spores.

Bacteria were abundant in the microflora liberated from the grain, in contrast to the fungi, which were present in the microflora liberated from hay. The molding patterns of grain and hay were different. The number of microbes liberated from baled hay and straw decreased sharply in midwinter but increased again in late spring. This occurrence may explain why the incidence of farmer's lung in Finland has been reported to be greatest in April (24).

The work methods on a farm greatly influence the farmer's exposure to airborne microbes. If cows are fed mainly hay, the requirement for dry feed is greater, and thus the exposure to the microbes is heavier than when silage is used as the main feed. A liquid manure system allows the farmer to use significantly less bedding material than does the common dry manure system. In addition, the liquid manure system requires that the farmer use material other than straw, and therefore the worst source of microbes is eliminated.

On most farms the worst possible combination is in use. Hay is baled and not storage dried. Grain is dried with unheated forced air. Straw is used as bedding. Manure is transferred manually. And cows are fed silage and baled hay.

Theoretically it could be calculated that, if the best possible alternatives of work methods were chosen, the exposure to microbes could be diminished to one-tenth, even without making any other changes on the farm. This decrease might be enough to lower the risk of respiratory symptoms caused by airborne microbes. No such intervention studies have been carried out as yet on farms.

\section{References}

1. Vaaranen V, Vasama M, Alho J. Ammattitaudit v. 1984 [Occupational diseases, 1984]. Helsinki: Institute of Occupational Health, 1985. (Katsauksia 77.)
Table 4. Daily amount of microbes liberated from the materials used with the two main methods of silage/liquid manure and dried hay/dry manure. The figures are estimated for the amount of materials needed for one dairy cow in a barn with separate stalls. (cfu $=$ colony-forming units)

\begin{tabular}{lcc}
\hline & \multicolumn{2}{c}{ Microbe estimate $\left(\times 10^{6} \mathrm{cfu}\right)$} \\
\cline { 2 - 3 } Material & $\begin{array}{c}\text { Silagel } \\
\text { liquid } \\
\text { manure } \\
\text { method }\end{array}$ & $\begin{array}{c}\text { Dried hayl } \\
\text { dry manure } \\
\text { method }\end{array}$ \\
\hline Silage & 1.4 & 0.7 \\
Graina & & \\
$\quad$ Grain treated with acid & 8.9 & 6.9 \\
$\quad \begin{array}{l}\text { Grain dried with heated } \\
\text { forced air }\end{array}$ & 20.1 & 15.6 \\
$\begin{array}{l}\text { Grain dried with unheated } \\
\text { forced air }\end{array}$ & 28.8 & 22.4 \\
Haya & & \\
$\quad \begin{array}{l}\text { Storage dried hay } \\
\text { Hay dried on poles } \\
\text { Hay dried on the ground, } \\
\text { collected loosely }\end{array}$ & 2.4 & 12.1 \\
Baled hay & 4.3 & 21.7 \\
Bedding & 7.4 & 37.0 \\
$\quad \begin{array}{l}\text { Wet sawdust } \\
\text { Wood shavings }\end{array}$ & 24.9 & 124.3 \\
Straw & & \\
\hline $\begin{array}{l}\text { Best combination } \\
\text { Worst combination }\end{array}$ & 0.03 & 0.3 \\
\hline
\end{tabular}

a Only one type of grain, hay, or bedding is generally used on a farm.

b Silage, grain treated with acid, storage dried hay, wet sawdust.

c Silage, grain dried with unheated forced air, baled hay, straw.

2. Vaaranen V, Vasama M, Alho J. Ammattitaudit v. 1985 [Occupational diseases, 1985]. Helsinki: Institute of Occupational Health, 1986. (Katsauksia 80.)

3. Vaaranen V, Vasama M, Jolanki R. Ammattitaudit v. 1986 [Occupational diseases, 1986]. Helsinki: Institute of Occupational Health, 1987. (Katsauksia 88.)

4. Vaaranen V, Vasama M, Jolanki R, Toikkanen J. Ammattitaudit v. 1987 [Occupational diseases, 1987]. Helsinki: Institute of Occupational Health, 1988. (Katsauksia 92.)

5. Vaaranen V, Vasama M, Jolanki R, Toikkanen J. Ammattitaudit $v$. 1988 [Occupational diseases, 1988]. Helsinki: Institute of Occupational Health, 1989. (Katsauksia 101.)

6. Terho EO, Lacey J. Microbiological and serological studies of farmer's lung in Finland. Clin Allergy 1979; 9:43-52.

7. Lacey J. The microflora of grain dusts. In: Dosman JA, Cotton DJ, ed. Occupational pulmonary diseases focus on grain dust and health. New York, NY: Academic Press, 1980:417-40.

8. Festenstein GN, Lacey J, Skinner FA, Jenkins PA, Pepys J. Self-heating of hay and grain in Dewar flasks and the development of farmer's lung antigens. J Gen Microbiol 1965;41:389-407.

9. Kotimaa MH, Mustonen MH, Husman KH. The effect of ADD-H preservative (ammonium propionate) on the moulding of baled hay. J Sci Agric Soc Finland 1983; 55:371-83.

10. Wallace HAH, Sinha RN. Fungi associated with hot spots in farm stored grain. Can J Plant Sci 1962;42: $130-41$. 
11. Ylimäki A, Koponen H, Hintikka E-L, et al. Mycoflora and occurrence of Fusarium toxins in Finnish grain. Espoo: Technical Research Center of Finland, 1979. (Publication 21.)

12. Gervais $\mathbf{P}$, Bensoussan $\mathbf{M}$, Grajek $W$. Water activity and water content: comparative effects on the growth of Penicillium roqueforti on solid substrate. Appl Microbiol Biotechnol 1988;27:389-92.

13. Gregory PH, Lacey ME. Mycological examination of dust from mouldy hay associated with farmer's lung disease. J Gen Microbiol 1963;30:75-88.

14. Andersen AA. New sampler for the collection, sizing and enumeration of viable airborne particles. J Bacteriol $1958 ; 76: 471-84$.

15. Kotimaa MH. Occupational exposure to spores in the handling of wood chips. Grana 1990;29:153-6.

16. Kolmodin-Hedman B, Malmberg P, Rask-Andersen A, Höglund S, Blomquist G, Palmgren U. Allergic alveolitis in workers exposed to moulds. Arh Hig Rada Toksikol 1983;34:351-5.

17. Kotimaa MH, Husman KH, Terho EO, Mustonen MH. Airborne molds and actinomycetes in the work environment of farmer's lung patients in Finland. Scand J Work Environ Health 1984;10:115-9.

18. Lacey J, Dutkiewicz J. Methods for examining the microflora of mouldy hay. J Appl Bacteriol 1976;41: $13-27$.

19. Lutey WR, Christensen CM. Influence of moisture con- tent, temperature, and length of storage upon survival of fungi in barley kernels. Phytopathology 1963;53: 713-7.

20. Charlick RH, Holden MR, Klinner WE, Shepperson G. The use of preservatives in haymaking. J Agric Eng Res 1980;25:87-97.

21. Mustonen M, Husman K, Kotimaa M, Kärenlampi L. Rehuviljan homeet ja sädesienet: itiöiden määrän ja laadun vaihtelut sekä esiintyminen työilmassa [Molds and actinomycetes in grain: the concentrations of spores in work environments]. Työterveyslaitoksen tutkimuksia 1983;1:46-60. (English summary.)

22. Mustonen M, Kotimaa M, Terho EO, Husman K, Kärenlampi L. Heinän ja rehun säilöntämenetelmät ja homepölyaltistus [The preservation of hay and silage and the mold exposure]. Helsinki: Institute of Occupational Health, 1984. (Työterveyslaitoksen tutkimuksia 206.) (English summary.)

23. Lacey J, Lord KA, King HGC, Manlove R. Preservation of baled hay with propionic and formic acid and a proprietary additive. Ann Appl Biol 1978;88:65-73.

24. Terho EO, Heinonen OP, Lammi S. Incidence of farmer's lung leading to hospitalization and its relation to meteorological observations in Finland. Acta Med Scand $1983 ; 213: 295-8$.

Received for publication: 10 April 1990 